Original paper UDC 1(510)(045)

1 Yangming, $\mathrm{W}$.

doi: $10.21464 / \mathrm{sp} 35110$

Received: 23 September 2019

\title{
Margus Ott
}

Tallinn University, Uus 21-3, EE-10111 Tallinn

motlus@gmail.com

\section{Wang Yangming's Notions of}

\section{Primary Knowledge and Primary Ability}

\section{Abstract}

The paper first establishes that Wang Yangming's 王陽明 (1472-1529) notion of primary knowledge (liangzhi 良知) does not entail subjective idealism but is rather related to the transcendental subjectivity in the phenomenological sense. Then, the paper discusses the question of whether Wang also has the concept of primary ability (liangneng 良能). The paper argues that it can be seen in two central topics of Wang: "knowledge and action are one" (zhixing heyi 知行合一) and "regarding Heaven and Earth and myriad things as one (rhizomatic) body” (以天地萬物為一體) or considering them as “originally one with my (rhizomatic) body” (本吾一體). It is shown how primary knowledge and ability are two aspects of the same phenomenon. It is true on the level of the virtual "rhizomatic body" (ti 體), not on the level of things considered as fully formed and actualized (xing 形), as they appear in the empirical mind, clouded by desires (yu 欲) that become fixated on the level of the actual. These desires can be discarded by the "extension of (primary) knowledge" zhi (liang)zhi 致(良)知. A parallel concept of “extension of (primary) ability” (zhi liangneng 致 良能), not used by Wang Yangming, could be added to the system.
\end{abstract}

\section{Keywords}

Wang Yangming, Chinese philosophy, intentionality, liangzhi, primary knowledge, primary ability, anthropocentrism, intersubjectivity

\section{Introduction}

WangYangming 王陽明 (1472-1529) is arguably the most influential Chinese philosopher of the Ming 明 period (1368-1644). Half a millennium earlier, during the Song 宋 dynasty $(960-1279)$, Confucianism had been revived after a long dominance of Buddhism and Daoism (it somewhat resembles the revival of antiquity during the European Renaissance). ${ }^{1}$ This form of Confucianism (that also borrowed heavily from Buddhism and Daoism) is called Neo-Confucianism by Western scholars. ${ }^{2}$ There were different schools of Neo-Confucianism, the most important of which was the "school of veins" 3 (li 理) or the "school of Chengs and Zhu", founded by brothers Cheng 程 and

This project was supported by the Estonian Research Council grant PRG319. I would also like to thank three anonymous reviewers who gave me extremely helpful feedback that helped to improve the draft.

2

For questions of this terminology, see Makeham 2010: $x$-xiv.
This is my translation of $l i$ 理, that I use also in an article on Zhu Xi (Ott 2020). This term has had a great variety of translations. An older dominant rendering was "principle". As Willard Peterson (1986: 22) notes, the problem is that "principle" is transcendent from the thing, it comes before and is separate from it and hence is not a good term to translate li. Peterson promoted "coherence" as a more 
developed by Zhu Xi 朱喜 (1130-1200). There was also another tradition, the so-called "school of heart/mind" (xin 心) of Lu Jiuyuan 陸九淵 (1139-1192). Wang Yangming, after a long dominance of the Cheng-Zhu school, reestablished the school of heart/mind that became to be also known as "the school of Lu and Wang" (see Ching 1976, De Bary 1989: 72-123, Ivanhoe 2009).

Certain philosophical positions have a profound truth but which are not easy to explain, and even if you have worked it out once, the next time you have to start all over again. Wang Yangming's statement that "outside of my heartmind there are no things" is one of such difficult statements, and it is useful to repeat its explanation (also because different scholars do it quite differently). This is the first goal of this paper. Secondly, this explication allows resonating Wang Yangming's ideas with contemporary philosophy (I make use of the philosophy of Edmund Husserl, Henri Bergson and Gilles Deleuze; resonances with modern Chinese philosophy, e.g. with Mou Zongsan 牟宗三, is a topic in its own right). ${ }^{4}$ This diachronic (and transcultural) dialogue can help to refresh both sides. Thirdly, this also shows the potential of Wang Yangming in the contemporary philosophical reflection. ${ }^{5}$

In this paper, firstly I establish that Wang Yangming's 王陽明 (1472-1529) notion of primary knowledge (liangzhi 良知) does not entail subjective idealism but is rather related to the transcendental subjectivity in the phenomenological sense. Then I discuss the question of whether Wang Yangming also has the concept of primary ability (liangneng 良能). The two terms of primary knowledge and primary ability were introduced by Mencius (372-289 BC) in the eponymous book Mencius, 7A.15 (see below, section 4), and the latter term was developed by certain scholars closer in time to Wang Yangming, especially by Zhang Zai (1020-1077). Yet, Wang Yangming discusses at length the first but only rarely mentions the latter (the opposite was true of Zhang Zai). Has Wang discarded it? In this paper I argue that the concept of primary ability for action is still there and that it can mainly be seen in two central topics of Wang Yangming: "knowledge and action are one" (zhixing heyi 知行合一) and "regarding Heaven and Earth and myriad things as one rhizome-body"6 (以天地萬物為一體) or considering them as "originally one with my rhizome-body" (本吾一體). Although most of the time Wang Yangming has ethical and self-cultivation concerns in mind, ontological inferences can be made as well. It is shown, firstly, that primary knowledge characterizes first of all transcendental, not empirical subjectivity, although the two are not separated. Secondly, it is shown how primary knowledge and ability are two aspects of the same phenomenon, and how this fact warrants the affirmation that all things are one rhizome-body with me. It is true on the level of the "rhizomatic body" ( $t i$ 體) or the energetic and flowing level, not on the level of things considered as fully formed and actualized (xing 形), as they appear in the empirical mind, clouded by desires ( $y u$ 欲) that become fixated on the level of the actual. These desires can be discarded by the "extension of (primary) knowledge" zhi (liang)zhi 致(良)知. A parallel concept of “extension of (primary) ability" (zhi liangneng 致良能), not used by Wang Yangming, could be added to the system. It is also important that primary knowledge and primary ability are inherently joyful. 


\section{Intentionality}

Wang Yangming 王陽明 (1472-1529) is famous for his saying that outside the heart-mind there are no things or affairs (心外無物 and 心外無事). At first glance, it might seem to imply a subjective idealism, i.e., the idea that only mind exists and that the reality is constituted by it. Take the following story: ${ }^{7}$

"The Teacher was roaming in Nanzhen. A friend pointed to flowering trees on a cliff and said, '[You say] there is nothing under heaven external to the mind. These flowering trees on the high mountain blossom and drop their blossoms of themselves. What have they to do with my mind?' The Teacher said, 'Before you look at these flowers, they and your mind are in the state of silent vacancy. As you come to look at them, their colors at once show up clearly. From this you can know that these flowers are not external to your mind." (CXL §275, WTC 222) ${ }^{8}$

先生遊南鎮，一友指巌中花樹問曰：「天下無心外之物：如此花樹，在深 山中自開自落, 於我心亦何相關? 」先生曰:「你未看此花時, 此花與汝 心同歸於寂：你來看此花時, 則此花顏色一時明白起來：便知此花不在你 的心外。」

The questioner supposes that the phrase "there is nothing outside the heartmind" is a solipsistic and idealistic affirmation that nothing physically exists outside my heart-mind; and this affirmation seems to be refuted by any external thing, like a beautiful blooming tree in the mountains. And Wang's reply might seem naïve at first glance. Or rather, it does not seem to be an answer at all: does not he simply affirm that if you do not look at the tree, you do not see it, and if you do, then the tree is visible?

But there is something deeper here. Usually, we suppose that things subsist objectively in a comprehensive space that also contains our own body as a material thing. And a small part of this space is perceived subjectively, namely the part that our sense organs give us access to. But if we investigate more

suitable term, both as internal coherence of the thing and external coherence of the thing with other things. This has become a newer standard for translating $l i$. Yet, I am afraid that it overstresses the integration part of the concept. Oxford dictionary gives two meanings for "coherence": "the quality of being logical and consistent" and "the quality of forming a unified whole". The Chinese authors were not so much concerned about a simple logical consistency, and unity is just one aspect of $l i$, the other being differentiation. I would like to take a hint from the traditional etymology of the character $l i$ 理 according to which it meant the veins in a jade (see Zhang 2002: 26-27; although a more correct etymology is that it represents a village $l i$ 里). It may be useful - at least for experimentation - to ground an abstract concept in a concrete phenomenon, and then to broaden it. From the veins in jade or wood, or veins of ore in the ground we would have a reference to the natural articulations of a thing; and from the veins that transport blood in the body or "arteries" (roads and channels) that transport people and goods in a village or city, we would have an idea of ontological articulations that channels and distributes life force or energy ( $q i$ 氣). Cf.
" $\mathrm{Li}$ may be compared to a network of roads" (Graham 1992: 58). Brook Ziporyn, who also opts for "coherence", has discussed this issue at length, see Ziporyn 2008, 2012, 2013.

4

There are several interesting comparisons of Wang Yangming with modern thinkers: e.g., phenomenology and existentialism (Jung 2011, Dong 2019), Peter Sloterdijk (Stanchina 2015), Christine Korsgaard (Chang 2015), John McDowell (Ivanhoe 2011), to name just a few.

5

I am grateful to an anonymous reviewer who asked me to bring out the general focus of this paper, and pointed out these three aspects, with which I indeed agree.

6

For an explanation of this term, see below, footnote 19 .

For some interpretations of this famous story, see Ivanhoe 2009: 109-110, Tian 2010: 302, Fung 2012: 277 and Ching 1976: 145. 
closely, then we must say that this very idea of an "all-encompassing space" is something present in my mind and affirmed by me. When we look for the origin of this idea in our experience, we see that it is the horizon of an ever ongoing synthesis: I always implicitly presuppose that outside my presently experienced space is another space and that I can make it perceptible if I, for instance, go out the door, or travel to another city, or if I use some technical device, like a TV camera, to make present other places. ${ }^{9}$ And when I pass my gaze on a landscape, there is a continuous process of coming into the field of vision (and then again, inside the field of vision, into the focal vision) and going out of it. What is in my field of vision stands out on the background of what is outside of it. The things are there, in the world, in the sense that they have their autonomy, and it is not my gaze that constitutes them from scratch. At the same time, everything that appears, appears in my mind, and in the case of visual perception, it has the structure of certain things in the field of vision on the background of other things outside of it. There are fulfilled perceptions and empty perceptions (see Zahavi 2003: 30), and the latter is not nothing: they are relatively undetermined, but they do not lack determination altogether, because in every perceptual scene I have certain expectations for what I shall probably perceive next. While looking at a valley in the mountains, I might see rocks and trees, perhaps creeks and waterfalls, houses and roads, but I do not expect to find the bottom of the ocean or a view on a unicellular in 1000 -fold magnification, etc. If I do see something unusual, my very surprise shows that I had a certain expectation that was not fulfilled. Thus, it is quite true that before I look at the flowers, they are in the state of "silent vacancy", as empty perceptual objects, and when I look at them, they are "clear", as fulfilled perceptual intentions.

The perceptual process has a temporal character, it is synthetical and, to use Husserlian terms, has the aspects of primal impression, retention and protention; that is, it retains some immediate past (retention) and tends towards an imminent future (protention) (see Husserl 1991, Zahavi 2003: 80-98). The primal impression of a certain visual or auditive perception has among its protentions slightly different perceptions or lack thereof (pitch darkness, silence), and vice versa, a primal impression of darkness or silence also has on its protentional horizon full visual or auditive perceptions. Thus, Wang Yangming says:

"Before the bell is struck [the sound], essentially speaking, startles the heaven and earth. After the bell is struck, it also just silences heaven and earth." (CXL §307, WTC 236, translation modified)

\section{未扣時原是驚天動地。即扣時也只是寂天默地。}

Silence is on the horizon of sound, and sound is on the horizon of silence. ${ }^{10}$ Seeing and hearing are perceptual modalities, our ways of dealing with the world, and through them, we have in view, we intend certain objects:

"The master of the body is the mind. What emanates from the mind is the intention. The original substance of the intention is knowledge, and wherever the intention is directed is a thing. For example, when the intention is directed towards serving one's parents, then serving one's parents is a 'thing'. When the intention is directed toward serving one's ruler, then serving one's ruler is a 'thing'. When the intention is directed toward being humane to all people and feeling love toward things, then being humane to all people and feeling love toward things are 'things', and when the intention is directed toward seeing, hearing, speaking, and acting, then each of these is a 'thing'. Therefore I say that there are neither veins nor things outside the mind." (CXL $\S 6$, WTC 14, translation modified) 
身之主宰便是心。心之所發便是意。意之本體便是知。意之所在便是物。 如意在於事親, 即事親便是一物。意在於事君, 即事君便是一物。意在於 仁民愛物，即仁民愛物便是一 物。意在於視聽言動，即視聽言動便是一 物。所以某說無心外之理, 無心外之物。

\section{In another place, Wang accepts his student's following definitions:}

"Body's master is heart-mind.

Heart-mind's lively clarity is knowledge.

Knowledge's coming forth and moving is intention.

What intention sees, is a "thing'."11 (CXL §78, my translation)

身之主為心,
心之靈明是知。
知之弡動是意。
意之所看為物。

Wang makes clear that he is speaking about intentional objects, ${ }^{12}$ not objects taken abstractly as separate from their appearance. Intention is what "comes forth from" or is "emitted by" ( $f a$ 發; “emanates" in Wing-tsit Chan's translation) the heart-mind; it is the "movement" (dong 動) of the heart-mind. ${ }^{13}$ The heart-mind itself, at the bottom, is not just empirical subjectivity, but transcendental.

CXL is Chuan xi lu 傳習錄, a collection of Wang Yangming's writings, dialogues and letters. The number refers to the section of the text as found in Wikisource: https://zh.wikisource.org/zh-hant/傳習錄 (accessed on 3 February 2020). WTC is Wing-tsit Chan's translation "Instructions for Practical Living" (Wang 1963) and the number refer to page numbers in that edition (Wade-Giles romanization has been changed into pinyin).

This idea is not even in contradiction with a finite astronomical space, because this perceptual possible synthesis is still supposed to go on indefinitely, only that at a certain point I may be back at the starting point, like if I continue to move straight ahead on the surface of the Earth, then after 40,000 km I will be back where I started from (although the comparison is not exact, because the universe expands, but Earth does not).

10

Of course, one can say with John Cage that there is no such thing as absolute silence, and that I always hear something, if not other things, then certain sounds from my body's interior. It might be questionable whether Cage in the anechoic chamber heard his blood circulation and nerve functioning (a low and high pitch noise) as he claimed, but it seems doubtless that he did in fact experience two distinct sounds, whatever their cause. So, silence may be reinterpreted in Bergsonian terms (similarly to the way he reinterprets "disorder" and "nothingness", see Bergson 1944: $240-257$ and 296-324), that it is the uninteresting background of the interesting (either in a positive or negative sense) sound. If I focus on the musicians' performance, their music is the "sound" and everything else is a silence. Or even more closely, their performance (positively interesting) is "sound"; disturbing sounds (like audience coughing, etc.) is "noise"; and all the rest is "silence". During 4'33" the "noise" itself becomes "music", but there may still be other things that I push out of my consciousness, e.g., sounds from my own body. In an anechoic chamber, even those bodily noises may become "music", if you are a Cage.

11

This idea in itself is not new, cf. for instance the phrase from the Guodian text "Nature from Decree Issues" (Xing Zi Ming Chu 性自 命出): “What one likes and what one dislikes, are things" (所好所惡, 物也; Middendorf 2008: 152).

12

“So, Wang's $w u$ is similar to Franz Brentano's intentional object." (Lee 1987: 33) - "To use the language of phenomenology, $y i$ is an intentional act in the widest sense." (Jung 2011: 44)

13

Movement in the sense of phenomenological directedness, not of empirical movement, as Chang (2017: 452) seems to have it. 


\section{Transcendental Subjectivity}

It is more useful to interpret Wang Yangming's heart-mind not as subjective idealism ${ }^{14}$ but as transcendental subjectivity in the phenomenological sense. ${ }^{15}$ It is not that the things outside my mind would cease to exist, but it draws the attention to the fact that (heart-)mind is the ground of all appearance, including the statement or imagination of "things outside my mind".

All the appearances of the world and affirmations about the world appear in my heart-mind and are affirmed by it. This heart-mind is not merely my heart-mind, my subjective inner world, which we might call a secondary, derived or empirical heart-mind, but it is the heart-mind as the condition of all appearance, a primary or transcendental mind. ${ }^{16}$ In the primary mind appear both subjectivity and objectivity, both the empirical "I" and empirical objects. This primary mind is not situated in my brain and is not even limited to my body, but it includes a whole context or landscape (both natural and social), of which the secondary mind and its empirical objects are just aspects or poles. Hence, the primary subjectivity can also be called the primary world, if we distinguish between a secondary or derived world as a collection of empirical objects, and the primary world of openness, where those objects can appear, with their specific modes of appearance (we shall come back to this topic below when we discuss the theme "all beings are one rhizome-body", see section 5).

This primary subjectivity is characterized by what Wang Yangming calls "primary knowledge" (liangzhi 良知). ${ }^{17} \mathrm{He}$ says that the primary knowledge is the original substance of the mind (xin zhi benti 心之本體, CXL §152 WTC 132), that it is (CXL 155) absolutely good, broad or unrestricted (kuoran 廓 然), inclusive (dagong 大公), quiet and unmoving (jiran budong 叔然不動), and possessed by all humans (人人之所同具者). Nothing can be added to it or subtracted from it. It is the "equilibrium before the feelings are aroused/emitted" (weifa zhi zhong 未發之中, a phrase from the classical text "Doctrine of the Mean").

We have to differentiate between two aspects of the mind (although Wang Yangming emphasizes that they cannot be separated). ${ }^{18}$

1. One is mind's "original substance" or "root rhizomatical body" (benti 本體). ${ }^{19}$ The primary knowledge characterizes it, it is the clearing or Lichtung that enables everything that appears, to appear (see Heidegger 1971: 54); ${ }^{20}$ it is neither good nor bad, neither tranquil nor moving, without past or future; a state before the emission of intentions and feelings (weifa 未發); holding fast to the "heavenly veins" (tianli 天理); it is bright and clear (ming 明, zhao 照), lively or nimble (ling 靈), and like a mirror (jing 鏡). ${ }^{21}$

2. The other is the empirical or psychological mind. This state has "already come forth", or is "already emitted" or "aroused" (yifa已發), that differentiates between good and bad, past and future, is moving and is characterized by greater or lesser obscuration, depending on the extent that it yields to the human desires (renyu 人欲) (we shall say more about it later).

However, it is still the same mind, and it cannot be really divided in this way:

"The state before [the feelings are] aroused/emitted exists in the state in which feelings have been aroused/emitted. But in this state there is not a separate state which is before [the feelings are] aroused/emitted. 
The state after [the feelings are] aroused/emitted exists in the state before the feelings are aroused/emitted. But in this state there is not a separate state in which [the feelings have been] aroused/emitted.

Both are not without activity or tranquility and cannot be separately characterized as active or tranquil."

(CXL, §157, WTC 137, translation modified)

\author{
未發在已發之中，而已發之中未嘗別有未發者在， \\ 已發在未發之中，而未發之中未嘗別有已發者存; \\ 是末嘗無動、靜，而不可以動、靜分者也。
}

14

Wang Yangming's "claim is quite far from Berkeley's subjective idealism" (Lee 1987: 33). See Husserl's refutation of subjective idealism in Husserl 1983: 128-130 (which shows that he considered it an easy misperception of his phenomenology)

15

Fung Yiu-ming (2012) considers liangzhi as a spiritual emanation from human persons to the universe, and brings out interesting similarities with neo-Daoism. However, at least for philosophical purposes, I find the comparison with phenomenology more fruitful

16

Of course, the "primary" and "secondary" do not refer to a rank in value but to a distinction in derivation: secondary knowledge presupposes primary knowledge as its foundation.

17

Wing-tsit Chan translates it as "innate knowledge", which is justified also by Mencius" saying (that introduced this philosophical concept, as we are going to see in the next section) that it is something you know without learning, and, so, one would think that this knowledge must be innate. However, there are several problems with this rendering. First, this term introduces an unnecessary connotation from the Western tradition, where the moderns fought over whether there are innate ideas ("rationalists") or not ("empiricists"), whereas no such debate was held about the liangzhi. In fact, the question was not about ideas but the mind itself that knows them (and in this sense also the empiricists would concede the existence of liangzhi, i.e., the existence of mind itself as a general capacity to receive impressions, to reflect, etc.), and the debate was not on whether such mind exists or not (everyone agreed on it) but on its relative importance in relation to practice: those who stressed the mind and its liangzhi (Lu-Wang school) laid more importance on personal attainment in oneself, whereas their opponents (Cheng-Zhu school) stressed more the importance of book-learning. And it should never be forgotten that although the debate became fierce at times, it was all about relative importance, because on the one hand, the final aim of also Cheng-Zhu school was personal understanding, and on the other hand LuWang school also had an educational curriculum with classical texts (which Wang often comments upon), and Wang Yangming himself stressed the importance of "investigating things" and "broadening the knowledge", which of course does not mean to lose oneself in external things (things taken without their relation to the mind), but it does involve the investigation of things in relation to the mind (or "rectification of thoughts in regard to things", see Ivanhoe 2009: 143, my emphasis), and not just empty contemplation of the mind "itself", without reference to its objects: "[T] he investigation of things is investigating the things of the mind, the things of the intention, and the things of knowledge." (CXL \$174, WTC 163, tr. modified) - 「格物」者, 格其 心之物也, 格其意之物也, 挌其知之物也 Furthermore, in case of liangzhi the focus was not on what was there before birth and what after but on the spontaneity of knowledge. $\mathrm{Li}$ angzhi is something you know spontaneously without learning, but in principle it is possible that at birth there are no ideas, but still you might know and act spontaneously in a certain way in certain conditions. It means that what is important is not the source of ideas but its mode, i.e., spontaneity. Another common translation is "intuitive knowledge". For a discussion on the translations of liangzhi, see Kern 2010: 123-124. Kern himself translates it as "ursprüngliche Wissen" (in that book, Iso Kern also distinguishes three chronologically distinct understandings of liangzhi in Wang Yangming: (1) as a spontaneous tendency towards good; (2) as perfectible consciousness of the ethical value of one's intentions; (3) as always clear and perfect source of all intentions; where the first two are empirical and the third transcendental). Ivanhoe (2009) translates it as "pure knowledge", which is a good translation, but "pure" remains too broad and vague for my purposes here. I opt to translate liangzhi as "primary knowledge" in the sense of phenomenologically primary, basic, from 
In a typical fashion for Neo-Confucians, when they distinguish different aspects, they hasten to stress that they are not really separate.

\section{Primary Knowledge (liangzhi 良知) and Primary Ability (liangneng 良能)}

We said that the "transcendental subjectivity" is characterized by the "primary knowledge" (liangzhi 良知), which is the basic or root character of the heart-mind. Now, this primary knowledge goes hand in hand with the primary ability for action (liangneng 良能). Both terms were introduced by Mencius (7A.15):

"Mencius said, 'The ability possessed by men without having been acquired by learning is primary ability, and the knowledge possessed by them without the exercise of thought is their primary knowledge. Children carried in the arms all know to love their parents, and when they are grown a little, they all know to love their elder brothers. Filial affection for parents is the working of benevolence. Respect for elders is the working of righteousness. There is nothing else to do but extend these to the world.", 22

孟子曰: 「人之所不學而能者, 其良能也; 所不慮而知者, 其良知也。孩 提之童, 無不知愛其親者; 及其長也, 無不知敬其兄也。親親, 仁也; 敬 長，義也。無他，達之天下也。」

Wang Yangming does not use these two terms equally: "primary knowledge" is one of his core concepts (perhaps "the" concept of Wang Yangming), ${ }^{23}$ found all over his later texts, whereas in Chuanxi lu 傳習錄 he uses "primary ability" only four times. ${ }^{24}$ However, the parallelism between these two, of the primary knowledge and primary capacity for action, comes out in two of Wang Yangming's central ideas: the unity of knowledge and action (zhixing heyi 知行合一), and that all beings form “one (rhizomatic) body” (yiti 一體). We shall discuss here the first topic, and in the next section, we shall come to the latter.

\section{Wang says:}

"Therefore, the Great Learning points to true knowledge and action for people to see, saying, they are 'like loving lovely sight and hating hateful odors'. Seeing lovely sight appertains to knowledge, while loving lovely sight appertains to action. However, as soon as one sees that lovely sight, she $\mathrm{e}^{25}$ has already loved it. It is not that she sees it first and then makes up her mind to love it. Smelling a hateful odor appertains to knowledge, while hating a hateful odor appertains to action. However, as soon as one smells a hateful odor, she has already hated it. It is not that she smells it first and then makes up her mind to hate it. A person with her nose stuffed up does not smell the hateful odor even if she sees a malodorous object before her, and so she does not hate it. This amounts to not knowing hateful odor. Suppose we say that so-and-so knows filial piety and so-and-so knows brotherly respect. They must have actually practiced filial piety and brotherly respect before they can be said to know them. It will not do to say that they know filial piety and brotherly respect simply because they show them in words. Or take one's knowledge of pain. Only after one has experienced pain can one know pain. The same is true of cold or hunger. How can knowledge and action be separated? This is the original substance of knowledge and action, which have not been separated by selfish intentions." (CXL §5, WTC $10-11$, translation modified $)^{26}$

故大學指箇真知行與人看，說『如好好色』，『如惡惡臭』。見好色屬 知, 好好色屬行。只見那好色時, 已自好了。不是見了後, 又立箇心去 好。聞惡臭屬知, 惡惡臭屬行。只聞那惡臭時, 已自惡了。不是聞了 後, 別立箇心去惡。如鼻塞人雖貝惡臭在前, 鼻中不曾聞得, 便亦不甚 
惡。亦只是不曾知臭。就如稱某人知 孝, 某人知弟。必是其人已曾行孝 行弟, 方可稱他知孝知弟。不成只是曉得說些孝弟的話, 便可稱為知孝 弟。又如知痛, 必已自痛了, 方知痛。知寒, 必已自寒了。知饑, 必已 自磯了。知行如何分得開? 此便是知行的本體, 不曾有私意隔斷的。

"I have said that knowledge is the direction for action and action the effort of knowledge, and that knowledge is the beginning of action and action the completion of knowledge. If this is understood, then when only knowledge is mentioned, action is included, and when only action is mentioned, knowledge is included." (CXL $\$ 5$, WTC 11)

which empirical "secondary knowledge" is derived by abstracting the objects of knowledge from their relation to the knower - although heuristically it is the other way around, we start from the naive understanding and arrive at the primary knowledge by an epochè.

18

Wang Yangming says that the states before and after the feelings are aroused/emitted are considered as two contrasting states "purely because later scholars talked about them separately” 只緣後儒將未發已發分說了 (CXL §307, WTC 236).

19

$T i$ 體 has been often translated as "substance" and sometimes as "essence", but they both have shortcomings. Both "substance" and "essence" are old metaphysical terms in the Western philosophy with ingrained meanings and connotations. (1) Sub-stans means "staying under", i.e., something that is and remains under the properties and through the changes. (2) "Essence" is what an entity is by necessity, as opposed to accidents, that are contingent. $T i$, on the other hand, is not under the properties and through the changes, but inside the appearances and changes themselves. It is also not defined as necessary and opposed to the contingent. It refers to the virtual level of being, of which beings and events are actualizations or “functionings" (yong 用). It is of the order of the veins 理 (see Ott 2020). Iso Kern (2010: 189-194) uses both of these translations (i.e., their German equivalents Wesen and Substanz), tying them to two different meanings of $t i$ or benti: "original essence" (as opposed to impure, obscured) and "substance" (as opposed to the "functions" or "expressions"). However, this distinction is questionable. Kern says that: "the whole set of problems reminds us of our classical discussions about the concepts of ousia, eidos, morphe, entelecheia or their Latin equivalents substantia, essentia, idea, forma" (Kern 2010: 192). I believe, on the contrary, that these similarities are misleading and rather bring in bad connotations. While I retain Wing-tsit Chan's translation "substance" or "body", it should be taken as a technical term and equivalent to (ben) $t i$, and all effort should be made to keep at bay the Western connotations of the terms. Recent- ly John Makeham and others have proposed to translate it as "(intrinsic) reality" (see, e.g. Angle 2018: 169), but I find this translation too vague, and it has also problematic etymological connotations: reality defined on the basis of "things" (res), that seems to be quite contrary to the sense of $t i$. The "things" or res would bring in connotations of things ( $w u$ 物) or forms (xing 形) - but in the Chinese tradition these belong to the "below-the-forms" (xingerxia 形而下), and should be kept apart from the "above-the-forms" (xingershang 形 而上), that is the realm of $t i$. An always acceptable alternative is to simply use the romanization $t i$, as in Makeham 2018, for instance. In itself, the word $t i$ 體 is a kind of "rhizomatic body", as Deborah Sommer (2008, 2010) explains (see also below, section 5).

20

Lichtung in German means a clearing in the forest, and Licht is light. There is a similar metaphor involved in Wang's clarity or brightness of the primary knowledge (see below).

21

The last three metaphors are correlated: according to an old metaphor often used in Buddhism and Daoism, mind is like a mirror in the sense that it without delay or discrimination reflects what appears in front of it. In this sense it is extremely lively, swift or nimble, because its original functioning (i.e., when the mirror is clear) is not hindered by anything, it adapts to everything, its reaction is immediate and contemporaneous with the event itself. But according to the metaphor, the mirror reflects only in case of light; and according to the third metaphor, the mind is brightness itself that illuminates everything.

22

Here I combine the translations of Legge, available at https://ctext.org/mengzi?searchu $=\% \mathrm{E} 8 \% 89 \% \mathrm{AF} \% \mathrm{E} 7 \% 9 \mathrm{~F} \% \mathrm{~A} 5$ (which is also the source of the Chinese original; accessed on 3 February 2020), and that of Van Norden (Mengzi 2008: 175). The word for "extend" ( $d a$ 達) is not the same as in Wang Yangming's "extension [zhi 致] of knowledge", taken from the "Great Learning". Mencius does not use the terms of $l i$ angzhi and liangneng elsewhere, and it may 
某嘗說知是行的主意。行是知的功夫。知是行之始。行是知之 成。若會 得時, 只說一箇知, 已自有行在。只說一箇行, 已自有知在。

In a Spinozist manner, for Wang Yangming, knowing and acting are not two consecutive phenomena but strictly contemporaneous. ${ }^{27}$ At first glance, one might find it strange: is it not a common experience that we first think something and then act according to the plan, or vice versa, that we first do something, and only later realize what we have done? But this understanding of knowing and acting abstracts and reifies them. When we investigate them concretely in their being, we find, like Wang Yangming says, that an understanding or plan is already an implicit action, and action involves a certain understanding. In this case, knowing and acting are not reified things any more but two existential aspects: a conative being (existence is acting, and inherently striving: the very fact that I endure implies a directedness towards the future, and its anticipation, based on the retention of the past that serves as the background of my current conation) and its self-relation (existence is related to itself, it is pre-reflectively in contact with itself), or differentiation and integration.

The primary knowledge refers to the ontological self-relation, or the function of "returning" that produces a self. With this, it creates a field of appearance, where everything that appears, can appear - and not only in the sense of coming into the clarity of fulfilled perceptions in distinction to unfulfilled ones, but more deeply, it creates the field itself where all the appearing in all its modes (perceptive, memorative, imaginative, etc.; as fulfilled and unfulfilled perceptions, etc.) can appear. This return or withdrawal creates an empty space or "clearing" - Lichtung - where the things can "appear".

The primary knowledge is in strict correlation with the primary ability for action, or intending, or differing, throwing oneself ahead of oneself. It implies a nexus of different actions, an indeterminacy of action. As Henri Bergson shows in his "Matter and Memory" (1990: 17-76), if all the influences in the universe would proceed without the slightest diversion or deflection, then nothing would appear, there would be no perception. It is only when those influences meet an entity with a certain capacity to act, with a certain indeterminacy as to its reaction, that things "appear"; namely, those things that are related to the interests of the actions of that body. Perception is a selection, and it presupposes a certain spontaneity of action..$^{28}$ Thus, what is needed is not just action, but an ability for action, i.e., that not all of the ability is fully actualized, but that some of it is in reserve. My concrete action takes place between the background of this "ability" 29 and the foreground of the action I perform right now. In the interaction between my body and the environment (when I try out a new skill or sport), new abilities may be developed (and others may be lost, due to injury, disease, disuse, etc.). My primary ability is my immediate presence in all of my capacity to act, my power or "dominance" (zhuzai 主宰, cf. CXL $\S \S 6,37,48,104,118,122,174,201,243,317,336$ ).

Since the affirmation that knowledge and action are one is valid first and foremost on the level of the "primary", the transcendental, we can say that in addition to the primary knowledge, Wang Yangming also has the notion of primary ability (perhaps the reason why he did not want to have a second term, primary ability explicitly, was that this could leave the impression that they are separate). 


\section{Forming One (Rhizomatic) Body with All Beings}

The previous consideration helps to understand Wang Yangming's teaching that one should "regard Heaven and Earth and myriad things as one (rhizomatic) body” (以天地萬物為一體, CXL §89) or consider them as “originally one with my (rhizomatic) body" (本吾一體, CXL §179) (cf. Tien 2010: 307, Angle 2010: 323-324, Ching 1976: 126-128). This part of Wang's philosophy forms a complement to his theory of primary knowledge. Together with the "knowledge and action are one" discussed above, the "one (rhizomatic) body" theory is a second important part of Wang Yangming's ontology from which we could deduce the notion of primary action.

As also in the case of the blossoming tree, an interlocutor points out a difficulty (CXL \$336): the bodies of animals and plants are different from my body, and even the bodies of other humans are different, so how is it possible that they form the same body? In his reply, Wang first extends this affirmation even further and says that also heaven and earth, gui- and shen-spirits form the same (rhizomatic) body with me. He explains that all are "permeated with one energy" (便是一氣流通的) and that it should be considered “from the point of view of the subtle incipient activating force of their mutual influence

be supposed that the adjective liang had the ordinary meaning of 'good'. However, namely due to the influence of this passage, liang acquired the meaning of 'intuitive,', 'innate'. Van Norden opts for "genuine" and Legge for "intuitive". For the sake of consistency in this paper, I retain the term "primary", although it is anachronistic in Mencius' case.

23

In a piece recorded in the "Omissions from the Chuanxi lu” (《傳習錄拾遺》), it is written: "The Master once said: 'Since my experience at Longchang, my thoughts have not been outside of the two words, liangzhi. However, I have not been able to articulate these two words [until now]. So I have had to use many words and expressions [to explain myself]. Fortunately, I have now made this discovery. I now see the whole [of truth] in one expression and I am really happy and my hands and feet start to dance with joy'.” (先生嘗曰: 「吾良 知二字, 自龍場以後, 便已不出此意。只是 點此二字不出。於學者言, 費卻多少辭說。 今幸見出此意。一語之下, 洞見全體, 真是 痛快, 不覺手舞足蹈。」) Ching 1976: 105; one sentence added and Wade-Giles changed into pinyin; Chinese text from: https://ctext. org/wiki.pl?if $=$ gb\&chapter $=673936 \quad$ (accessed on 3 February 2020). Wang Changzhi 王昌祉 (Wang 1936: 60-63) makes it a point how Wang Yangming had a need for this concept, and the innovation it implied in terms of the creation of concepts, because liangzhi was not used as a concept before Wang Yangming.

24

It is the other way around for Zhang Zai, who stressed the primary ability (Chan 1963: 509).
25

Although Wang Yangming spoke with a male audience in mind, I have used the female pronouns to make the point that in principle there is no distinction between men and women in this respect. Grammatically, it is not incorrect, since the Chinese language does not mark gender.

26

The expressions "loving a lovely sight" and "hating a hateful odor" are taken from Tiwald and Van Norden 2014: 191.

27

For Spinoza, thought and extension are two attributes of the same substance: they express the same substance under two different attributes.

28

Bergson has in mind mainly living beings, but that can be prolonged "downwards" towards simpler entities, because, for instance, even a chemical element, due to its structure (its valences), i.e., its modes of action, interacts with its surroundings in a certain way and selects those other elements with which it reacts, leaving aside all others, and it may have different possible modes of interaction, actualized in other occasions (it is perhaps not a coincidence that life is based on carbon, the most versatile element, with its 9 different integer oxidation states).

29

For this topic, cf. Husserl's notion of "I can" (Behnke 2011). 
and response" (在感應之幾上看). It is only on this level that things form one body, not on the level of their “forms" (xingti 形體). The notion of “trigger" ( $j i$ 幾) that Wing-tsit Chan translates as "subtle incipient activating force" (bringing out different aspects in the meaning of the term) refers to the very beginning of an individuation process that proceeds from the interpenetrating $^{30}$ (Wang Yangming uses, for instance, the term "interpenetrating" or "intermingled" hunran 渾然, ${ }^{31}$ CXL 157) up until the juxtaposed. ${ }^{32}$

All beings and events have common energy, but they seem separated from the viewpoint of their actualized forms. Wang Yangming supports this commonality with the following argument:

"It is for this reason that such things as the grains and animals can nourish humans and that such things as medicine and minerals can heal diseases. Since they share the same energy, they penetrate into one another.” (CXL \$274, WTC 221-222, translation modified)

故五穀、禽獸之類皆可以責人, 藥石之類皆可以療疾, 只為同此一氣, 故 能相通耳。」

We might say that even in a naïve, secondary or derived attitude, and without any knowledge of chemistry or physics, we intend some parts of our surroundings as consubstantial with our own body in the sense that I can assimilate them through nourishment, or use them as medicine. And even more generally, I discover myself initially not as alien to this world but already acting in it. In Deleuzian-Spinozist sense (see Deleuze 1988: 54-58, Deleuze 2007) we can consider our ontogenesis as a process by which we learn how to make "one body" with certain things or environments. For example, when we learn how to manipulate things, or learn to walk or to swim - in those cases, we form an assemblage or "one rhizomatic body" with those things and environments. We form practical questions: How does a hammer behave in my hand? How does my body behave in the water? When we can hammer a nail or swim in a river, we know how to manage some important singularities of those things and environments, in conjunction with the singularities of our own body. We know how they "work" together, and the distinction between the inner and outer is never clear-cut. A hammer may become experientially part of my body when I hammer. And my hand may become experientially alien to my body, for instance, when I have slept on it, and it has become numb. In principle, this "ability" extends, either directly or indirectly, to all there is, so that it is a fact of our embodied capacity for action that "all things form one (rhizomatic) body" (a sensorimotor equivalent to the intentional "primary world" mentioned above in section 2).

\section{Intersubjectivity and First-Person Point of Access}

We must take a closer look at the "one-body" theory, because Wang Yangming accords a strong priority to the human mind, and the question arises whether it is an anthropocentric discourse:

"Human being is the mind of Heaven and Earth." ${ }^{33}$

人是天地的心

"My lively clarity is the master of heaven and earth and spiritual beings."

我的靈明, 便是天、地、苨、神的主宰。 
"Separated from my lively clarity, there will be no heaven, earth, gui- and shen-spirits, or myriad things." (All three passages from CXL §336, WTC 257-8, tr. mod.)

\section{天、地、鬼、神、萬物, 離卻我的靈明, 便沒有天、地、鬼、神、萬物} 了;

"The primary knowledge of humans is the same as the true knowledge of plants and trees, tiles and stones. Without the primary knowledge inherent in humans, plants and trees, tiles and stones cannot be what they are. This is not true of them only. Even Heaven and Earth cannot be what they are without the primary knowledge that is inherent in humans." (CXL §274, WTC 221, tr. mod.)

人的良知，就是草、木、瓦、石的真知:

若草、木、瓦、石無人的良知，不可以為草、木、瓦、石矣。

豈惟草、木、瓦、石為然, 天、地無人的良知, 亦不可為天、地矣。

We have repudiated an idealistic interpretation that would consider the human mind as constitutive of all the universe. Indeed, the penultimate citation above continues thus:

“....and separated from heaven, earth, gui- and shen-spirits, and myriad things, there also will not be my lively clarity."

\section{我的靈明，離卻天、地、鬼、神、萬物，亦沒有我的靈明。}

However, Wang Yangming may still be thought to uphold strong anthropocentrism. When he says that the primary knowledge of humans is the same as that of plants and trees, etc., does he mean that in reality, they do not have anything comparable to human being's primary knowledge and that all their self-relation is reducible to human being's self-relation? From the background knowledge of the Chinese tradition, we know that no traditional school denied a real self-relation and subjectivity to other beings (indeed, it was not only granted to other animals but often extended also to plants, stones and tiles). ${ }^{34}$ And if Wang Yangming held such a view, he should also have to tackle the problem of the existence of subjectivity or self-relation of other human beings, which he does not pursue, and which indeed, a fortiori, was not a topic in the traditional Chinese philosophy. Instead, it is in this context that he pres-

\section{0}

For a discussion of this term in relation to Gilles Deleuze, see Ott 2019.

\section{1}

Wing-tsit Chan's translation of 'undifferentiated' is not very good, because it would imply a homogeneous block; the things referred to (human heart-mind and Heavenly veins) are not undifferentiated - in that case we would have no personal mind different from that of other people and entities - but they are enveloped in each other: my mind envelops in itself all other minds.

\section{2}

In Ott 2019 I claim that Zhuangzi's notion of $j i$ is situated on the level of Deleuze's intensive differences. In Wang Yangming (see CXL $\S 281)$, the $j i$ seems to be closer to Zhu Xi's notion of the Great Ultimate and Deleuze's dark precursor which is the very initiator of the actualization process.

33

Pronounced by his student and accepted by him. It refers to the traditional saying from the "Book of Rites" (Ch. 7, "Evolution of Rites"): "Human being is the mind of Heaven and Earth" (人者, 天地之心也), cf. also CXL $\S 178$.

34

One of the most radical expressions of it is found in Zhuangzi's 'Knowledge Wanders North" (Ch. 22): "Master Easturb inquired of Zuangzi, saying, "Where is the so-called Way present?' 'There's no place that it is not present', said Zhuangzi. 'Give me an example so that I can get an idea', said Master Easturb. 'It's in ants', said Zhuangzi. 'How can it be so 
ents his idea that "all things form one (rhizomatic) body". Human's mind does have a priority, but it is only a relative one:

"For at bottom Heaven, Earth, the myriad things, and humans form one (rhizomatic) body. The point at which this unity is manifested in its most refined and excellent form is the lively clarity of the human mind.” (CXL §274, WTC 221-2, tr. mod.)

\section{蓋天、地、萬物與人原是一體, 其發放之最精扈, 是人心一點靈明。}

It may be argued in phenomenological terms that the being of me as a subject depends on my relation to other subjects, as Dan Zahavi says:

“... the self-being of each and every subject depends upon its relation to other subjects. (...) In its full concretion no subject (not even the Other) can exist independently of Others." (Zahavi 2003: 115)

As Zahavi explains, it is intersubjectivity that maintains the possibility of objectivity and is the guarantee against subjective idealism:

"[T]he objects cannot be reduced to being merely my intentional correlates if they can be experienced by Others as well. The intersubjective experienceability of the object guarantees its real transcendence, so my experience (constitution) of transcendent objects is necessarily mediated by my experience of its givenness for another transcendent subject, that is, by my experience of a foreign world-directed subject." (Zahavi 2003: 115-116)

"When I realize that my object of experience can also be experienced by Others, I also realize that there is a difference between the thing in itself and its appearance for me. (...) Thus, it only makes sense to speak and designate something as a mere appearance, as merely subjective, when I have experienced other subjects and thus acquired the concept of intersubjective validity." (Zahavi 2003: 118)

Already in perceptual intentionality (like the view of a blossoming tree referred to in section 1) intersubjectivity is present as co-subjectivity (Zahavi 2003: 120). ${ }^{35}$ Thus, when Wang Yangming introduces at this point the idea that all beings are one (rhizomatic) "body", it need not be taken as a lapse into naïve metaphysics, an affirmation about the world independent of the transcendental subjectivity, but instead in the sense of a fundamental intersubjectivity - ever more so because the word for "body", $t i$ 體, is a kind of rhizomatic body that can be common to several beings, so that they are consubstantial and without hierarchy (see Sommer 2008, 2010 and the chapter on "Rhizome" in Deleuze and Guattari 1987: 1-25). ${ }^{36}$

At the same time, it is still true that there is a factual point of access ${ }^{37}$ into this rhizome: my own body and mind, my consciousness and ability for action.

"There is no community without I-centering, and consequently no generative intersubjectivity without a transcendental primal ego in which intersubjectivity can unfold itself (...). [T]he 'we' stretches from me onward (...). [T] he transcendental analysis of the historical past, of previous generations, and more generally any analysis of meaning that transcends the finiteness of the subject, must always take its point of departure in the first-person perspective." (Zahavi 2003: 139)

Without this anchoring point, the habitual phenomenological life-world collapses:

"Consider the dead person. Her spirit has drifted away and dispersed. Where are her heaven and earth, gui- and shen-spirits, and myriad things?” (WTC 257-258, §336)

今看死的人，他這些精靈游散了，他的天、地、鬼、神、萬物尚在何處? 


\section{Fixation on the Actual}

What obscures the primary heart-mind and keeps us fixated on actualized forms are "desires" ( $y u$ 欲). Desire might be defined as a conatus that intends its object as merely actual, separated from its source, its virtuality or the "veins" ( $l i$ 理), from primary knowledge and primary ability. It is correlated with "selfishness" or "partiality" ( $s i$ 私) a calculation of "profit" ( $l i$ 利), bringing out the distinction between good and evil (shan' $e$ 善惡):

"When you want to enjoy flowers, you will consider flowers good and weeds evil. But when you want to use weeds, you will then consider them good. ${ }^{38}$ Such good and evil are all products of the mind's likes and dislikes. (...). The state of having neither good nor evil is that of principle in tranquility. Good and evil appear when energy is perturbed. If the energy is not perturbed, there is neither good nor evil, and this is called the highest good." (CXL §101, WTC 63, tr. mod.)

子欲觀花, 則以花為善, 以草為惡。如欲用草時, 復以草為善矣。此等善 惡, 皆由汝心好惡所生。(...) 無善無惡者理之靜。有善有惡者氣之動。不 動於氣, 即無善無惡。是謂至善。

But is it possible at all to behave without the distinction between good and bad? Our very conative existence makes a selection according to "goodness". Even at the level of organs and cells, the very fact that we breathe, circulate blood, produce ATP, etc., is a striving for a certain "good" (e.g. $\mathrm{O}_{2}$ ), and dealing with a certain "bad" $\left(\mathrm{CO}_{2}\right)$, not to mention our daily activities and plans. But as Wang Yangming explains, he does not want to do away with all kinds of axiological distinctions, but only the reflective ones:

low?' 'It's in panic grass.' 'How can it be still lower?' 'It's in tiles and shards.' 'How can it be still lower?' 'It's in shit and piss.' Master Easturb did not respond." (Mair 1994: 217, tr. mod.)

東郭子問於莊子曰:「所謂道, 惡乎在？」 莊子曰:「無所不在。」東郭子曰: 「期而 後可。」莊子曰: 「在螻蟻。」曰: 「何其 下邪？」曰：「在稊稗。」曰：「何其愈 下邪？」曰:「在瓦璧。」曰: 「何其愈甚 邪？」曰: 「在屎溺。」東郭子不應。

35

One of the most vivid, forceful and playful expressions of it is the story of Zhuangzi and Huizi on the bridge on river Hao, discussing the happiness of the fish (Ch. 17, see Ames and Nakajima 2015). There are different possible interpretations of that short story, but it seems most plausible that Zhuangzi implies an intersubjectivity both with fellow human beings (Huizi) and with other creatures (fish).

36

Sommer argues that there are strong vegetative connotations in the $t i$ body, especially in relation to the capacity for vegetative reproduction (the old alternative version of the character is 体, the left part of which is "human" and the right part of which is "root"): when you cut a potato, then each part of it with a node can give rise to a new plant and each of them in a sense is the parent plant.
Humans can also form a $t i$ body, especially through ritual consumption of food; the word for "ritual" $l i$ 禮, being often brought together with the $t i$ 體; the right part of which is the same). Sommer summarizes it as follows: "[T] he $t i$ body can be understood as follows: as a polysemous corpus of indeterminate extent that can be partitioned into subtler units, each of which is often analogous to the whole and shares a fundamental consubstantiality and common identity with that whole. $T i$ bodies can potentially extend in all directions and can exist in multiple, overlapping layers or valences. Boundaries between valences are often unmarked or are obscure. When a $t i$ body is fragmented into parts (literally or conceptually), each part retains, in certain aspects, a kind of wholeness or becomes a simulacra of the larger entity of which is a constituent." (Sommer 2008: 294) - Sommer does not mention rhizome, but the multiplicity, lack of hierarchy and univocity bring it close to Deleuze and Guattari's concept of the rhizome.

37

Julia Ching also speaks about a "beginning" or a "starting point" (1976: 56, 115).

38

This relativity or relationality of terms was a recurrent topic for Zhuangzi. 
"The sage (...) in his non-distinction of good and evil, merely makes no special effort whatsoever to like or dislike, and is not perturbed in her energy. As she pursues the kingly path and sees the perfect excellence she by herself completely follows the Veins of Nature and it becomes possible for her to assist in and complete the universal process of production and reproduction and apply it for the benefit of the people..$^{39}$ (...) Not making a special effort to like or to dislike does not mean not to like or dislike at all. A person behaving so would be devoid of consciousness. To say 'not to make a special effort' [buzuo 不作] merely means that one's likes and dislikes completely follow the Veins of Nature and that one does not go on to attach to that situation a bit of selfish/intentional thought. This amounts to having neither likes nor dislikes." (CXL $\$ 101$, WTC 64, translation modified)

聖人無善無惡。只是無有作好, 無有作惡。不動於氣。然遵王之道, 會其 有極。便自一循天理。便有箇裁成輔相。( …)

不作好惡, 非是全無好惡。卻是無知覺的人。謂之不作者, 只是好惡一循 於理。不去，又著一分意思。如此即是不曾好惡一般。

Thus, the question is about whether one "makes a special effort" (zuo 作) and is "perturbed" or “moved" in one's energy (dong yu qi 動於氣) or not. A sage takes the viewpoint of the whole of nature (of everything as "one body") ${ }^{40}$ and for this reason is "broad and impartial" (kuoran dagong 廓然大公), and has empathy with animals and plants, stones and tiles ("Inquiry on the Great Learning", see WTC 272; cf. Blakeley 2003).

The sage does make distinctions between good and bad; it is only that they are not forced and separated from the judgements and conatuses of other beings, and take them into account. She forms one body with the universe, but at the same time there is a "relative importance among things" (houbao 厚薄, lit. "thick and thin", CXL 276, WTC 222; cf. Ching 1976: 130):

"Take for example the body, which is one. If we use the hands and the feet to protect the head, does that mean that we especially treat them as less important? Because of their ontological veins this is what should be done.

We love both plants and animals, and yet we can tolerate feeding animals with plants.

We love both animals and men, and yet we can tolerate butchering animals to feed our parents, provide for religious sacrifices, and entertain guests.

We love both parents and strangers. But suppose here are a small basket of rice and a platter of soup. With them one will survive and without them one will die. Since not both our parents and the stranger can be saved by this meager food, we will prefer to save our parents instead of the stranger. This we can tolerate.

We can tolerate all these because by the ontological veins these should be done.

As to the relationship between ourselves and our parents there cannot be any distinction of this or that or of greater or lesser importance. For being humane to all people and feeling love for all comes from this affection toward parents. If in this relationship we can tolerate any relative importance, then anything can be tolerated.

What the Great Learning calls relative importance means that according to primary knowledge there are natural veins which should not be skipped over." (CXL §274, WTC 222-223, translation modified)

比如身是一體, 把手足捍頭目, 豈是隔要薄手足, 其道理合如此。 禽獸與草木同是愛的，把草木去養禽獸，心又忍得：

人與禽獸同是愛的，宰禽獸以養親與供祭祀，燕賓客，心又忍得：

至親與路人同是愛的, 如篭食豆美, 得則生, 不得則死, 不能兩全, 寧救 至親，不救路人，心又忍得：這是道理合該如此。

及至吾身與至親，更不得分別彼此厚薄。蓋以仁民愛物皆從此出，此處可 忍，更無所不忍矣。《大 學》所謂厚薄，是良知上自然的條理。

Our relation to our parents is the "starting point" for empathy. This "interpenetration" of subjectivities gives the concrete material for the extension of 
empathy; ${ }^{41}$ empathy gives us access to others, and this can be elaborated. We do not "tolerate" discrimination or harm towards our parents (and siblings, see CXL $\S \S 30,93,181)$, and this lends itself to be extended to other people, creatures and even stones, although there are at the same time distinctions between our relation to them. ${ }^{42}$ This leads to the "extension of primary knowledge".

\section{Extension of Primary Knowledge}

Parallel to the distinction between secondary and primary, empirical and transcendental subjectivity, we can speak about relative good and evil, and absolute good and evil:

"[Good and evil] are only in your mind. Following the Veins of Nature is good, while perturbing the energy is evil." (CXL §101, WTC 65, translation modified)

\section{只在汝心。循理便是善。動氣便是惡。}

Following the veins is good in the absolute sense (the "highest good", zhishan 至善 of the Great Learning) and perturbing or "moving" the energy is absolutely "bad" in the sense that it is there that the distinction or separation between good and bad is formed: where my good is separated from that of another being, and reified as an object of desire, a "profit". ${ }^{43}$ This is the most important task of self-cultivation: to extend the knowledge (zhizhi 致知) or

39

The whole phrase from "to assist..." to the end of the sentence translates the four characters 裁成輔相. They refer to the Book of Changes, explanation to hexagram 11 that Legge translates: " (The trigrams for) heaven and earth in communication together form Tai. The (sage) sovereign, in harmony with this, fashions and completes (his regulations) after the courses of heaven and earth, and assists the application of the adaptations furnished by them, - in order to benefit the people.” 天地交泰, 后以 財成天地之道, 輔相天地之宜, 以左右民: available at: https://ctext.org/book-of-changes/tai2/ens (accessed on 3 February 2020); caicheng 財成 is equivalent to caicheng 裁 成). Wing-tsit Chan has, instead of the "courses of heaven and earth", used another phrase "the universal process of production and reproduction", which comes from another place in the "Book of Changes", the Xici commentary: "Production and reproduction is what is called (the process of) change 生生之謂易. This process of incessant production happens through the alteration of yin-yang which is the course of heaven and earth."

40

And in this sense, she looks, in Spinoza's terms, from the standpoint of eternity, sub specie aeternitatis, although the metaphors are different and here it is not the standpoint of eternity or temporal whole, but of the universe's ever renewing capacity for (re)generation.
41

In the Western tradition, love between man and woman is often presented in a similar fashion as a prototype for the cultivation of devotion and of the "love of thy neighbour".

42

This is the classical Confucian response to Mozi who expounded "universal love/care" and accused Confucians of being selfish and nepotist: later Confucians accepted that we should care about everyone, but they added that we should start from what is closer - and take this as a starting point for extension.

43

However, it is not clear what does it entail for the relation with other beings. I, as a human being, actualize certain Heavenly Veins, which also means that I kill other beings for food. Is it impartial or not? Is it allowable or not? If it is, then is it allowable always or with some restrictions? Does it have profit in view or not? We saw that there are degrees of involvement (more for relatives than strangers, more for humans than animals, more for animals than plants, etc.). Is it ontologically based on the "access point" of my subjectivity? But what determines the degree of involvement? Some prior similarity? But how to justify it ontologically? Or is it possible to found it upon a philosophy of difference in a Deleuzian sense? For the "maintenance" of difference, there are perhaps requirements that mostly entail much of the distinctions 
to extend the primary knowledge (zhi liangzhi 致良知) to overcome those separations.

"What I mean by the investigation of things and the extension of knowledge is to extend the primary knowledge of my mind to each and every thing. The primary knowledge of my mind is the same as the Heavenly Veins. When the Heavenly Veins in the primary knowledge of my mind are extended to all things, all things will attain their veins. To extend the primary knowledge of my mind is the matter of the extension of knowledge, and for all things to attain their veins is the matter of the investigation of things. In these the mind and veins are combined into one." (CXL $\S 135$, WTC 99, translation modified)

若鄙人所謂致知格物者, 致吾心之良知於事事物物也。吾心之良知, 即所 謂「天理」也。致吾心良知之「天理」於事事物物, 則事事物物皆得其理 矣。致吾心之良知者, 致知也。事事物物皆得其理者, 格物也。是合心與 理而為一者也。

"Extension of knowledge" is one of the elements in the traditional Confucian self-cultivation program laid out in the "Great learning": to cultivate one's self (xiushen 修身), rectify one's heart-mind (zhengxin 正心), make intention sincere (chengyi 誠意), extend one's knowledge (zhizhi 致知) and investigate things (gewu 格物) (in CXL §317, Wang Yangming gives a lengthy explanation of the mutual relations of these aspects, and often discusses them elsewhere).

As Wang Yangming explains in CXL $\S 317$ and also in the famous story of the (failed) contemplation of bamboo in his youth (CXL §318), things in the world are innumerable, and it is futile to search for the truth in external things, but "the effort to investigate things is only to be carried out in and with reference to one's body and mind" (其格物之功, 只在身心上做, CXL §318, WTC 249). ${ }^{44}$ On the one hand, Wang Yangming does not stress as much as Zhu Xi the investigation of things for their own sake, ${ }^{45}$ but makes a phenomenological point, that all appearing things should be investigated in relation to the body and mind they appear to and which cannot be left out from a comprehensive study of things. On the other hand, Wang Yangming is not wholly contemplative, as certain Buddhist or Daoist currents might have been; he always stresses the extension of knowledge and the investigation of things, and in this respect, another phenomenological point should be emphasized: that the mind always exists in relation to something extra-mental, and most of the mental acts have their intentional objects. As Wang says:

"The intention never exists in a vacuum. It is always connected with some thing or event." (CXL $\S 201$, WTC 189, translation modified)

意未有懸空的, 必著事物,

Initially, Wang Yangming taught his students to meditate, but he found out that they became lethargic, and overly liked stillness; so, he later laid more stress on the "extension of (primary) knowledge" [zhi(liang)zhi 致(良)知], i.e., grasping the primary knowledge both in tranquility and in activity (CXL $\S 262)$.

It is precisely the extension of knowledge (and its consequences to other selfcultivation aspects) that makes the difference between a sage and a commoner.

"Only the perfect sage in the world has quickness of apprehension, intelligence, insight, and wisdom. How deep and mysterious this formerly seemed! But as we look at it today, we realize that these qualities are common to all humans. Human ears are by nature quick of apprehension, her eyes intelligent, and her mind and thought have insight and wisdom. The sage is the only one 
who can demonstrate them with one effort. What enables her to do so is her primary knowledge, and the reason ordinary people cannot do so is that they do not extend their knowledge. How clear! How simple! And how easy!” (CXL §283, WTC 225-226, translation modified)

『惟天下之聖，為能聰明睿知』，舊看何等玄妙，今看來原是人人自有 的; 耳原是聰，目原是明，心思原是睿知，聖人只是一能之爾，能處正是 良知。眾人不能，只是箇不致知。何等明白簡易！

This is a potentially democratic and emancipating common idea in the Chinese philosophical tradition that "everybody can become a Yao or a Shun", that everyone has "Buddha-nature" in themselves or that "the Way is everywhere"; it has been in the tradition from the very beginning, when Confucius accepted students from poor families (like Yan Hui), and also when the Mohists undertook radical democratization of the cultural field.

Primary knowledge is in itself perfect, and nothing can be added to it or subtracted from it. So, what is translated as "extension" ( $z h i$ 致 $)^{46}$ does not mean expansion or enlargement of the primary knowledge in itself but the expansion of its scope or purport by letting it "shine" through more easily and through less "clouds". It means to include the aspect of primary knowledge into my consideration of all things and affairs, which also leads me to understand, as we saw, that I form one (rhizomatic) body with all other beings, and that their subjectivity or self-relation is included in my subjectivity or self-relation: that we form one "rhizomatic body". According to the two ontological aspects of differentiation and integration, first, by the action or other-relation in differentiation we form one body according to our "energy" ( $q i$ 氣); and second, by the subjectivity or self-relation other self-relations are implied in my own self-relation, forming an intersubjective web or a network of ontological veins ( $l i$ 理).

Taking into account the strict parallelism of knowing and acting, we could say that in addition to the "extension of primary knowledge" (zhi liangzhi 致 良知) there is also an “extension of primary ability” (zhi liangneng 致良能). Although Wang himself did not use the latter phrase, he certainly did believe that the ability of action has ontological meaning and that this side should be cultivated (he simply used just one phrase, the "extension of knowledge"). Just as the extension of knowledge does not mean merely an empirical extension of things that one knows but rather the inclusion of the aspect of

mentioned above. My capacity to differ from myself and to "generate and regenerate" (shengsheng 生生) might need certain assemblages with other humans, and first of all, or typically, with my close ones, but also with animals, plants, stones, landscapes, etc. Yet, there seems to be much room for discussion.

44

For a phenomenological analysis of Wang Yangming's gewu and chengyi, see Dong 2019.

45

First of all, it meant reading texts and dealing with moral questions. In a way, this question has become even more relevant today, where we may take the "investigation of things" literally as the technical and scientific investigation of the world, which is even more dominant and capillary today than was Cheng-Zhu style "investigation of things" in Wang Yangming's days.

46

The International Encoded Han Character and Variant Database (http://chardb.iis.sinica.edu. tw/, accessed on 3 February 2020) enumerates among the meanings of this word: "send", "convey"; "reach", "attain"; "pass on", "transmit"; "implement"; "induce"; "cause"; "seek to obtain", "make extreme effort"; "examine carefully"; "attentive"; "extremely", "very". So, this word is not directly related to spatial extension, and the phrase of "extension of (primary) knowledge" 致 (良) 知 could also be translated as "arriving at (primary) knowledge" or "seeking to obtain" it, etc. 
primary knowledge in every act of consciousness, neither does the extension of primary ability simply mean that one performs many and/or great empirical deeds but, rather, that one includes the primary ability in every act. My every action is an action of the rhizomatic body of all beings. This, of course, puts greater responsibility upon my actions, and it is also true that in some cases, it may enhance empirical performance because the primal ability is inexhaustible. Before it can be exhausted, I die. But this huge prospect does not make one overwhelmed, depressed or gloomy.

\section{Primary Knowledge is Joyful}

On the contrary, the extension of knowledge offers an englobing joy:

"Joy is (...) the original substance of the mind. Though it is not identical with the joy of the seven feelings, it is not outside of it. Sages and worthies have another true joy, it is true, but it is shared by ordinary people except that these people do not realize it though they have it. Instead they bring upon themselves a great deal of sorrow and grief and, in addition, confusion and selfabandonment. Even in the midst of all these, this joy is not absent. As soon as a single thought is enlightened, and one examines herself and becomes sincere, the joy is present right there." (CXL166, WTC 147-8, tr. mod.)

樂是心之本醴, 雖不同於七情之樂, 而亦不外於七情之樂; 雖則 聖賢別 有真樂，而亦常人之所同有，但常人有之而不自知，反自求許多憂苦，自 加迷棄。雖在憂苦迷棄之中, 而此樂又未嘗不存, 但一念開明, 反身而 誠，則即此而在矣。

Joy can be on two levels: empirical, as one of the "seven feelings", and transcendental, as a function of "returning to one's body" or "reflecting on oneself" (fanshen 反身, when one "examines" oneself, in Chan's translation). This is parallel to Spinoza's saying:

"When the mind contemplates itself and its power of action, it feels joy." (Ethics, 3p53, my translation)

Thus, the sage's life, that spontaneously actualizes the virtual veins of the universe, is not cold and dispassionate but joyful. Self- and other-relation in primary knowledge and primary ability are by themselves joyful. And the moment one is in contact with one's existence, it is called "sincerity" (cheng 誠), which is one of the important terms in the "Great Learning" mentioned above and which is also one of the key elements in Wang's ontological ethics (which lies outside the scope of the present paper).

\section{Conclusion}

In this paper, I have investigated two interrelated notions: primary knowledge (liangzhi 良知) and primary ability (liangneng 良能). Primary knowledge is one of Wang Yangming's core concepts, and he discusses it in several places in his works. It is best conceived of as a characteristic of the transcendental subjectivity, or as the "clearing", Lichtung where everything that appears, appears.

Wang Yangming seldom discusses the primary ability, but this concept can be shown to be at work in his notions "knowledge and action are one" (zhixing heyi 知行合一) and "regarding Heaven and Earth and myriad things as one (rhizomatic) body" (以天地萬物為一體). It means that originally "knowing” 
and "acting" cannot be separated and that they are two aspects of the same phenomenon, viz. the self-relation and other-relation, or integrating and differing - that are constitutive of all things and events.

The primary knowing gives everything the "place" where it can appear; and like in case of the primary ability, there is a "communion" (Merleau-Ponty 2005: 246, 248, 373, 434), in principle, with all things in the universe. In one sense, everyone is endowed with the primary knowledge and ability, but it is obfuscated by mind's fixating on the objects of its desires, by the "moving" of energy ( $q i$ 氣), and the task of self-cultivation is to reach for the primary knowledge and ability, to "extend the knowledge and investigate things" (zhizhigewu 致知格物). “To extend" does not mean to enlarge in scope or volume but to clear the obscurity, "to let shine through". "To investigate" does not mean to lose oneself in external things, but to take them together with the knowing mind and embodied action, with the primary knowledge and primary action. It is intrinsically rewarding, as the self-relation on the level of primary knowledge is joyful.

\section{References}

Ames, Roger; Nakajima, Takahiro. 2015. Zhuangzi and the Happy Fish. Honolulu: University of Hawai'i Press.

Angle, Stephen C. 2010. "Wang Yangming as a Virtue Ethicist". In: Makeham, John (ed.). Dao Companion to Neo-Confucian Philosophy. London: Springer. PP. 315-335. doi: https://doi.org/10.1007/978-90-481-2930-0_15.

Angle, Stephen C. 2018. "Buddhism and Zhu Xi's Epistemology of Discernment". In: Makeham, John (ed.). The Buddhist Roots of Zhu Xi's Philosophical Thought. New York: Oxford University Press. PP. 156-192.

Behnke, Elizabeth A. 2011. "Edmund Husserl: Phenomenology of Embodiment". In: Internet Encyclopedia of Philosophy. Available at: https://www.iep.utm.edu/husspemb/ (accessed on 23 September 2019).

Bergson, Henri. 1944. Creative Evolution. Translated by Arthur Mitchell. New York: Random Books.

Bergson, Henri. 1990. Matter and Memory. Translated by Nancy Margaret Paul, W. Scott Palmer. New York: Zone Books.

Chan, Wing-tsit. 1963. A Source Book in Chinese Philosophy. Princeton: Princeton University Press.

Chang, Tzu-li. 2015. "Personal identity, moral agency and liang-zhi: a comparative study of Korsgaard and Wang Yangming”. Comparative Philosophy 6 (2015) 1. PP. 3-23. doi: https://doi.org/10.31979/2151-6014(2015).060105.

Chang, Tzu-li. 2017. "Liangzhi and the Interpretative Obfuscation Regarding Knowledge". Frontiers of Philosophy in China 12 (2017) 3. PP. 450-465.

Ching, Julia. 1976. To Acquire Wisdom. The Way of Wang Yangming. New York: Columbia University Press.

De Bary, William Theodore. 1989. The Message of the Mind in Neo-Confucianism. New York: Columbia University Press.

Deleuze, Gilles. 1988. Spinoza, Practical Philosophy. Translated by Robert Hurley. San Francisco: City Lights Books.

Deleuze, Gilles. 2007. “On Spinoza. Lectures at Vincennes”. In: Lectures by Gilles Deleuze. Available at: http://deleuzelectures.blogspot.com/2007/02/on-spinoza.html (accessed on 23 September 2019). 
Deleuze, Gilles; Guattari, Félix. 1987. A Thousand Plateaus. Capitalism and Schizophrenia II. Translated by Brian Massumi. Minneapolis: University of Minneapolis Press.

Dong, Minglai. 2019. "Correcting things as correcting feelings: a phenomenological study of Wang Yangming's doctrine of gewu”. Comparative Philosophy 10 (2019) 1. PP. 18-37. doi: https://doi.org/10.31979/2151-6014(2019).100106.

Fung, Yiu-ming 馮耀明. 2012. “Wang Yang-ming's Theory of Liang-zhi. A New Interpretation of Wang Yang-ming's Philosophy". Tsing Hua Journal of Chinese Studies 42 (2012) 2. PP. 261-300.

Graham, Angus. 1992. Two Chinese Philosophers. The Metaphysics of the Brothers Ch'eng. La Salle: Open Court.

Heidegger, Martin. 1971. "The Origin of the Work of Art". Poetry, Language, Thought. Translated by Albert Hofstadter. New York: Harper \& Row.

Husserl, Edmund. 1983. Ideas Pertaining to a Pure Phenomenology and to a Phenomenological Philosophy. First Book: General Introduction to a Pure Phenomenology. Translated by Fred Kersten. The Hague: Nijhoff.

Husserl, Edmund. 1991. On the Phenomenology of the Consciousness of Internal Time (1893-1917). Translated by J. B. Brough. Dordrecht: Kluwer.

Ivanhoe, Philip. 2009. Readings from the Lu-Wang School of Neo-Confucianism. Indianapolis - Cambridge: Hackett.

Ivanhoe, Philip. 2011. "McDowell, Wang Yangming, and Mengzi's Contributions to Understanding Moral Perception". Dao 10 (2011) 3. PP. 273-290. doi: https://doi. org/10.1007/s11712-011-9222-5.

Jung, Hwa Yol. 2011. Transversal Rationality and Intercultural Texts. Essays in Phenomenology and Comparative Philosophy. Athens - Ohio: Ohio University Press.

Kern, Iso. 2010. Das Wichtigste im Leben. Wang Yangming (1472-1529) und seine Nachfolger über die "Verwirklichung des ursprünglichen Wissens" 致良知. Basel: Schwabe.

Lee, Jig-chuen. 1987. "Wang Yang-ming, Chu Hsi, and the Investigation of Things". Philosophy East and West 37 (1981) 1. PP. 24-35. doi: https://doi.org/10.2307/1399081.

Makeham, John. 2010. "Introduction". In: Makeham, John (ed.). Dao Companion to NeoConfucian Philosophy. London: Springer. PP. ix-xlii.

Makeham, John. Ed., 2018. The Buddhist Roots of Zhu Xi's Philosophical Thought. New York: Oxford University Press.

Mengzi. 2008. Mengzi. With selections from traditional commentaries. Translated by Bryan W. Van Norden. Indianapolis - Cambridge: Hackett.

Merleau-Ponty, Maurice. 2005. Phenomenology of Perception. Translated by Colin Smith. London - New York: Routledge.

Middendorf, Ulrike. 2008. "Again on Qing. With a translation of the Guodian Xing zi ming chu”. Oriens Extremus 47. PP. 97-159.

Ott, Margus. 2019. "Deleuze and Zhuangzi: Actualization and Counter-actualization". Asian Studies 7 (2019) 1. PP. 315-335. doi: https://doi.org/10.4312/as.2019.7.1.315-335.

Ott, Margus. 2020. "Deleuzian (re)interpretation of Zhu Xi”. Asian Studies 8 (2020) 2. PP. 281-310. https://doi.org/10.4312/as.2020.8.2.281-310.

Peterson, Willard. 1986. “Another look at li 理”. Bulletin of Sung and Yüan Studies 18 (1986). PP. 13-31.

Sommer, Deborah. 2008. "Boundaries of the Ti Body". Asia Major 21 (2008) 1. PP. 293324.

Sommer, Deborah. 2010. "Concepts of the Body in the Zhuangzi”. In: Mair, Victor (ed.). Experimental Essays on Zhuangzi. Dunedin: Three Pines Press. PP. 212-228.

Stanchina, Gabriella. 2015. “Zhi 知 as unceasing dynamism and practical effort. The 
common root of knowledge and action in WangYangming and Peter Sloterdijk". Journal of the ECNU Simian Institute for advanced studies in Humanities 1 (2015). PP. 280-307.

Tien, David. 2010. "Metaphysics and the Basis of Morality in the Philosophy of Wang Yangming". In: Makeham, John (ed.). Dao Companion to Neo-Confucian Philosophy. London, Springer. PP. 295-314.

Tiwald, Justin; Van Norden, Bryan. 2014. Readings in Later Chinese Philosophy: Han to the $20^{\text {th }}$ Century. Indianapolis - Cambridge: Hackett.

Wang, Changzhi 王昌祉. 1936. La philosophie morale de Wang Yangming. Shanghai: Imprimerie de T'ou-sè-wè - Paris: Librarie Orientaliste P. Geuthner.

Wang, Yangming. 1963. Instructions for Practical Living and Other Neo-Confucian Writings by Wang Yang-Ming. Translated by Wing-tsit Chan. New York: Columbia University Press.

Zahavi, Dan. 2003. Husserl's Phenomenology. Stanford: Stanford University Press.

Zhang, Dainian. 2002. Key Concepts of Chinese Philosophy. New Haven: Yale University Press.

Ziporyn, Brook. 2008. "Form, Principle, Pattern, or Coherence? $L i$ 理 in Chinese Philosophy". Philosophy Compass 3 (2008) 3. PP. 401-422. doi: https://doi.org/10.1111/ j.1747-9991.2008.00135.x.

Ziporyn, Brook. 2012. Ironies of Oneness and Difference. Coherence in Early Chinese Thought. Prolegomena to the Study of Li. New York: SUNY Press.

Ziporyn, Brook. 2013. Beyond Oneness and Difference. Li 理 and Coherence in Chinese Buddhist Thought and Its Antecedents. New York: SUNY Press.

\section{Margus Ott \\ Pojmovi prvobitno znanje i prvobitna sposobnost kod Wanga Yangminga}

\section{Sažetak}

Rad najprije utvrđuje da iz pojma prvobitnog znanja (liangzhi 良知) Wanga Yangminga王陽明 (1472. - 1529.) ne slijedi subjektivni idealizam te da je vezan za transcendentalnu subjektivnost u smislu fenomenologije. Zatim, raspravlja se o pitanju ima li Wang pojam prvobitne sposobnosti (liangneng 良能). Argumentira se da se može naći u dvije glavne Wangove teme - „znanje i radnja jedno su« (zhixing heyi 知行合一) te »razmatrati Nebo i Zemlju i mnoštvo stvari kao jedno (rizomatično) tijelo« (以天地萬物為一體) ili ih smatrati 》izvorno jednim s mojim (rizomatičnim) tijelom« (本吾一體). Pokazuje se da su prvobitno znanje i sposobnost dva aspekta isto fenomena. Istinito je na razini virtualnog »rizomatskog tijela« (ti 體), a ne na razini stvari razmatranih kao potpuno oblikovane i aktualizirane (xing 形), kako se pojavljuju u empirijskom umu, zamagljeni žudnjama (yu 欲) koje postaju fiksirane na razini aktualnog. Te se žudnje mogu razriješiti putem »proširenja (prvobitnog) znanja《 zhi (liang)zhi 致(良)知. Usporedni pojam "proširenja (prvobitne) sposobnosti« (zhi liangneng 致良能), koji Wang Yangming ne koristi, može se unijeti u sustav.

\section{Ključne riječi}

Wang Yangming, kineska filozofija, intencionalnost, liangzhi, prvobitno znanje, prvobitna sposobnost, antropocentrizam, intersubjektivnost 


\title{
Margus Ott \\ Die Begriffe ursprüngliches Wissen und ursprüngliches Können bei Wang Yangming
}

\begin{abstract}
Zusammenfassung
Die Arbeit stellt zunächst fest, aus dem Begriff des ursprünglichen Wissens (liangzhi 良知) bei Wang Yangming 王 陽 明 (1472-1529) folgt es nicht ein subjektiven Idealismus und mit der transzendentalen Subjektivität im phänomenologischen Sinne zusammenhängt. Als Nächstes wird die Frage diskutiert, ob Wang den Begriff des ursprünglichen Könnens (liangneng 良 能) verwendet. Es wird argumentiert, dass er sich in Wangs zwei Hauptthemen finden lässt - ,Wissen und Handeln sind eine Einheit“ (zhixing heyi 知行合一) wie auch in ,Himmel und Erde und unzählige Dinge als einen (rhizomatischen) Körper betrachten“ (以天地萬物為一體) oder sie als die ,ursprüngliche Einheit mit meinem (rhizomatischen) Körper" ansehen (本吾 一體). Es stellt sich heraus, dass das ursprüngliche Wissen und Können zwei Aspekte desselben Phänomens sind. Die Wahrhaftigkeit befindet sich auf der Ebene des virtuellen ,,rhizomatischen Körpers" (ti 體) und nicht auf der Ebene der Dinge, die als vollständig geformt und aktualisiert aufgefasst werden (xing 形), wie sie in der empirischen Vernunft in Erscheinung treten, getrübt vom Begehren (yu 欲), das auf der Ebene des Aktuellen fixiert wird. Dieses Begehren kann durch die ,Erweiterung des (ursprünglichen) Wissens“ (zhi (liang)zhi 致(良) 知) verworfen werden. Der parallele Begriff „Erweiterung des (ursprünglichen) Könnens“ (zhi liangneng 致良能), den Wang Yangming nicht verwendet, kann in das System eingeführt werden.
\end{abstract}

\section{Schlüsselwörter}

Wang Yangming, chinesische Philosophie, Intentionalität, liangzhi, ursprüngliches Wissen, ursprüngliches Können, Anthropozentrismus, Intersubjektivität

\section{Margus Ott \\ Les concepts de connaissance innée et de faculté innée chez Wang Yangming}

\begin{abstract}
Résumé
Dans un premier temps, ce travail démontre que du concept de connaissance primaire (liangzhi 良知) de Wang Yangming 王陽明 (1472-1529) ne s'ensuit pas l'idéalisme subjectif et qu'il est en lien avec la subjectivité transcendantale au sens phénoménologique. Ensuite, la question de savoir si la philosophie de Wang Yangming contient le concept de pouvoir primaire (liangneng 良能) est abordée. Il est argumenté qu'il est possible de le retrouver au sein de deux notions élaborées par Wang Yangming - «la connaissance et l'action ne font qu'un 》 (zhixing heyi 知行 合一) et " considerer le Ciel et la Terre et la multitude des choses comme corps (rhizomatique) » (以天地萬物為一體) - ou considérer qu'ils «font originellement un avec mon corps (rhizomatique)» (本吾一體). Il est démontré que la connaissance primaire et la faculté primaire sont deux aspects du même phénomène. C'est vrai au niveau virtuel du " corps rhizomatique " (ti 體), et non pas au niveau des choses considérées comme formées et actualisées (xing 形) dans leur totalité, telles qu'elles apparaissent dans la raison empirique obscurcie par les désirs (yu 欲) qui se fixent au niveau de l'actuel. Il est possible de se défaire de ces désirs par " extension de la connaissance (primaire) (zhi (liang)zhi 致(良)知). Le concept comparatif de " extension de la connaissance (primaire) » (zhi liangneng 致良能), qui n'est pas présent chez Wang Yangming, peut être introduit dans son système.
\end{abstract}

\section{Mots-clés}

Wang Yangming, philosophie chinoise, intentionnalité, liangzhi, connaissance innée, faculté innée, anthropocentrisme, intersubjectivité 